\title{
High-marsh invertebrates are susceptible to eutrophication
}

\author{
David Samuel Johnson*
}

Ecosystems Center, Marine Biological Laboratory, 7 MBL Street, Woods Hole, Massachusetts 02543, USA

\begin{abstract}
In salt marshes, high-marsh habitats are infrequently flooded (typically only during spring tides). Organisms in these habitats, however, may still be susceptible to the effects of increased nutrients delivered by tidal water (i.e. eutrophication). In a Massachusetts salt marsh, I examined the responses of the epibenthic invertebrates in the Spartina patens-dominated high marsh to long-term (7 yr) and landscape-level (4-5 ha) nutrient enrichment. In this ecosystemlevel experiment, nutrients ( $\mathrm{N}$ and $\mathrm{P}_{i} \sim 15 \times$ reference conditions) were added to the flooding waters of tidal creeks - which flooded the high marsh during spring tides - to mimic cultural eutrophication. Three detritivores: Melampus bidentatus (gastropod), Philoscia vittata (isopod), and Orchestia grillus (amphipod) numerically dominated the benthic invertebrate community ( $97 \%$ by abundance). These species had higher densities (47 to $199 \%$ increase) in enriched versus reference creeks. Melampus size structure shifted to larger individuals with enrichment. End-of-season aboveground biomass and detritus stocks of $S$. patens did not differ between treatments; thus, increased litter quality and/or alternative food-source increases (e.g. microbes) led to increased detritivore density/biomass. Predator densities (spiders and Tabanus larvae) increased 125 to $160 \%$ with enrichment, likely due to increased prey densities (including Orchestia and Philoscia). Analysis of similarities (ANOSIM) revealed that communities were dissimilar between treatments; differences were driven primarily by changes in detritivore abundance. These results suggest that despite being infrequently flooded and thus infrequently exposed to elevated nutrients, high-marsh invertebrates are susceptible to eutrophication. Hence, the high marsh should be integrated into our understanding of how eutrophication impacts saltmarsh functioning.
\end{abstract}

KEY WORDS: Epifauna $\cdot$ Salt marsh $\cdot$ Spartina alterniflora $\cdot$ Plum Island Estuary

\section{INTRODUCTION}

Eutrophication (defined here as increased inorganic nutrient inputs) is a pervasive problem in coastal ecosystems worldwide. Because salt marshes are downstream of often large watersheds that funnel human-derived nutrients from terrestrial inputs, the function and structure of marshes may be particularly susceptible to the effects of nutrient enrichment (Deegan et al. 2007). Plants are dominant organisms in salt marshes and nutrients, par- ticularly nitrogen, generally stimulate plant production (e.g. Valiela et al. 1975, Mendelssohn 1979, Deegan et al. 2007, Darby \& Turner 2008, Wimp et al. 2010). The high levels of primary production in salt marshes fuel food webs; thus, nutrient effects at the primary producer level may propagate throughout the food web (Wimp et al. 2010). In fact, consumers often mirror plant responses to nutrient enrichment with increased densities or biomass (Deegan et al. 2007, Johnson \& Fleeger 2009, Wimp et al. 2010). 
A typical New England salt marsh is bounded by an intertidal swath of streamside, tall-form Spartina alterniflora (saltmarsh cordgrass), with the high marsh often being dominated by Spartina patens (saltmeadow hay) (Miller \& Egler 1950, Niering \& Warren 1980). There is relatively little work focused on $S$. patens habitats. Recent work has focused on anthropogenic impacts on these habitats including invasive species introductions (Warren et al. 2001), haying (Buchsbaum et al. 2009), and climate change (Charles \& Dukes 2009, Gedan \& Bertness 2010). The effect of nutrient enrichment on the high marsh remains relatively unknown (although see Fleeger et al. 2008; Johnson \& Fleeger 2009).

While low-marsh habitats are inundated during daily (or twice-daily) high tides, high-marsh habitats are often only inundated during spring tides or storm surges. These infrequently flooded habitats may thus not appear to be strongly influenced by nutrient enrichment delivered via tidal water relative to the daily-flooded low-marsh habitats. The few studies that have examined the high marsh for nutrient effects on animal communities have focused on sediment-dwelling fauna (Fleeger et al. 2008, Johnson \& Fleeger 2009) or insect communities, which typically occupy the plant canopy (Stiling et al. 1991, Bertness et al. 2008). Thus, no work has examined enrichment effects on high-marsh epibenthic invertebrates (sometimes referred to as 'epifauna').

In New England high-marsh habitats, the epibenthic invertebrate community is dominated by detritivores (e.g. snails, amphipods) (Fell et al. 1982). Predators, such as spiders, are also present within this community. Given that nutrient enrichment can stimulate densities across multiple trophic levels and shift invertebrate community structure in Spartina alterniflora-dominated habitats (e.g. Wimp et al. 2010), similar results can be expected in Spartina patens-dominated habitats.

For this study, I took advantage of a novel nutrientenrichment experiment in a northeast Massachusetts (USA) salt marsh to examine the response of epibenthic invertebrates in the Spartina patens-dominated high marsh. Nutrients were applied to the flooding waters of tidal creeks that also flood the high marsh providing a large sampling area (4-5 ha), and enrichment had been ongoing for $7 \mathrm{yr}$ at the end of this study. Thus, I was able to examine ecosystem-level responses of invertebrates to long-term enrichment. I hypothesized that nutrient enrichment would stimulate invertebrate densities and alter community structure.

\section{MATERIALS AND METHODS}

\author{
Study site
}

This study was conducted in 5 tidal creeks in northeast Massachusetts, USA. These creeks are all located within the broader salt marsh in the Plum Island Estu$\operatorname{ary}\left(42^{\circ} 44^{\prime} \mathrm{N}, 70^{\circ} 52^{\prime} \mathrm{W}\right.$; Fig. 1). Four creeks drain into the Rowley River and the remaining creek empties directly into the sound (Fig. 1). All creeks have similar faunal, plant, and physical characteristics (Deegan et al. 2007, Johnson et al. 2007, D. S. Johnson et al. unpubl. data). Vegetation patterns are typical of New England marshes (Miller \& Egler 1950, Niering \& Warren 1980). Creek-side Spartina alterniflora (smooth cordgrass, $160 \mathrm{~cm}$ shoot height) dominates the lowest elevation (seaward edge) of the vegetated marsh platform and is replaced by $S$. patens (mixed with Distichlis spicata) near mean high water. Patches of stunted $S$. alterniflora (40 cm shoot height) monocultures occupy poorly drained sites of the high marsh. In this system, S. patens occupies 60 to $70 \%$ of the aerial extent of the vegetated marsh platform. Based on percentage of time inundated, creek-side $S$. alterniflora habitats are inundated $\sim 10 \%$ of the time, whereas $S$. patens habitats are inundated only during the highest spring tides or during storm surges, which results in this habitat being inundated $\sim 4 \%$ of the time during the growing season (May to September).

\section{Nutrient enrichment}

Two creeks were selected to receive nutrient enrichment and 3 creeks remained as references. To mimic anthropogenic nutrient enrichment, nutrients were added in solution to the water column of each creek with a targeted concentration of 50 to $70 \mu \mathrm{M}$ $\mathrm{NaNO}_{3}{ }^{-}$and $6 \mu \mathrm{M} \mathrm{PO}_{4}{ }^{3-}$ with each flooding tide. This was achieved by pumping a concentrated nutrient solution into the twice-daily flooding waters, with the pump rate being adjusted every $10 \mathrm{~min}$ throughout the flooding tide to maintain targeted concentrations. Nutrients were added at least $120 \mathrm{~d}$ during the plant growing season (from mid-May to mid-September) of each year from 2004 to 2010. This level of nutrient enrichment was $\sim 15 \times$ higher than concentrations found in reference creeks. Nutrient enrichment concentrations are typical of those found in estuarine systems designated as moderately-to-severely eutrophic by the Environmental Protection Agency (2002). The current method of enrichment differed from other marsh nutrient enrichment studies using hand-broad- 

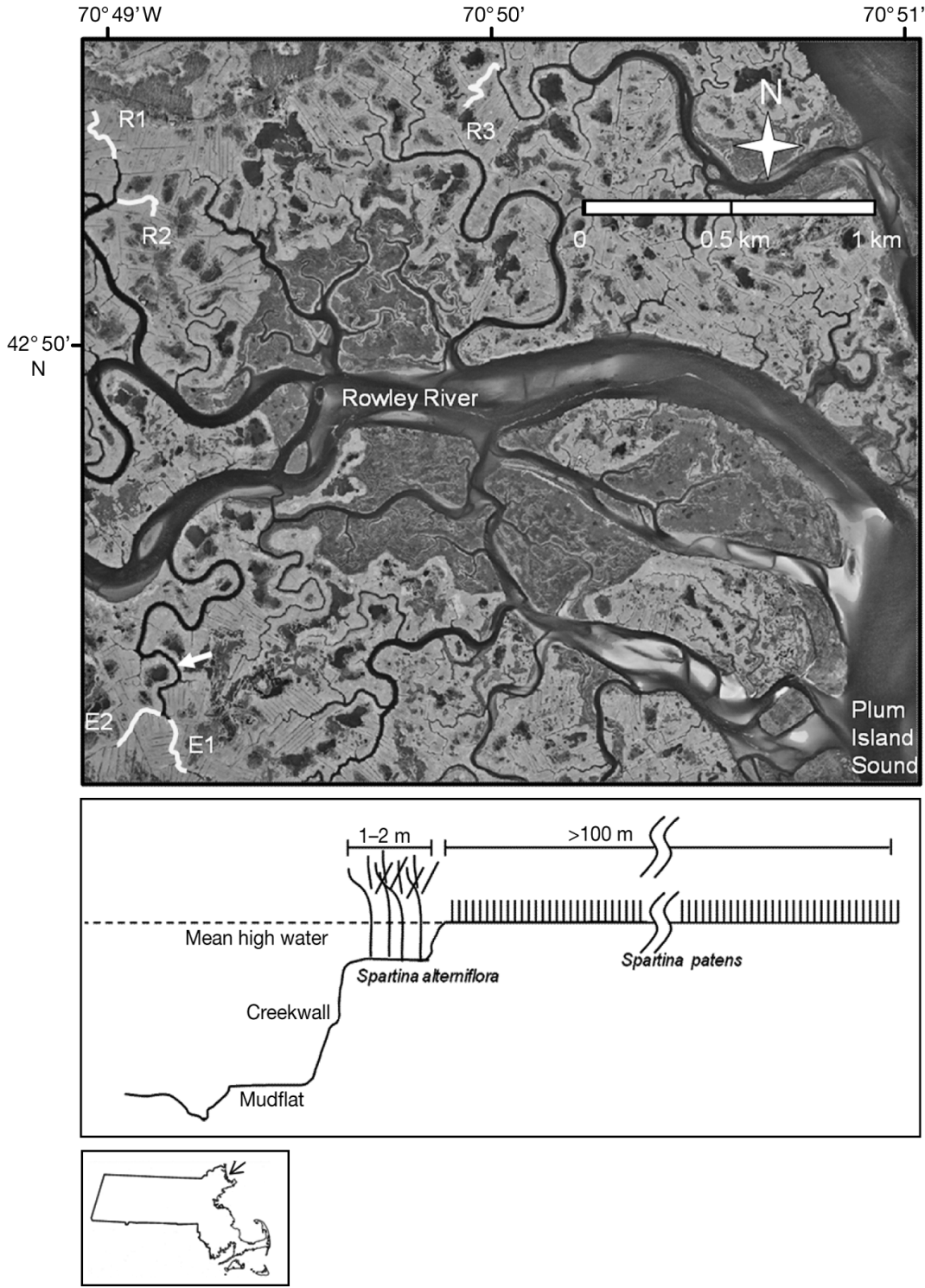

Fig. 1. Top: aerial photograph of Rowley River marshes (base map from MassGIS 2009); bottom: outline of the state of Massachusetts (USA) with arrow indicating the location of Plum Island Estuary. In the photograph: light colored areas are extensive Spartina patens high-marsh habitats; dark areas within these habitats are ponded areas; dark areas near the Rowley River are lower-elevation and extensive Spartina alterniflora habitats; white areas are experimental tidal creeks used in this study; E1 and E2 are nutrient enriched creeks; R1, R2 and R3 are reference creeks; and white arrow: point of nutrient addition. Middle: cross-section of typical tidal creek (not to scale). Although Spartina patens often extends beyond $100 \mathrm{~m}$ from the tidal creek, sampling was conducted within $75 \mathrm{~m}$ of the $S$. alterniflora/S. patens border

cast dry fertilizer on small plots $\left(\mathrm{m}^{2}\right)$ in at least 2 ways: (1) it mimics how anthropogenic nutrients are delivered to the marsh (i.e. via the flooding waters), and (2) the spatial scale of the application is large (4-5 ha). The high-marsh habitats had an average loading rate of $15 \mathrm{~g} \mathrm{~N} \mathrm{~m}^{-2} \mathrm{yr}^{-1}$ and similar concentrations were recorded throughout the high marsh (Deegan et al.
2007). The 2 enriched creeks form a confluence from which nutrients were applied (Fig. 1); however, the distance between sampling areas was at least $200 \mathrm{~m}$. Reference creeks were at least 1 aerial $\mathrm{km}$ from the point of nutrient addition (Fig. 1).

\section{Sampling}

Late-summer (August-September) invertebrate surveys were completed in Year 6 (2009) and Year 7 (2010) of enrichment. This timing allowed us to collect end-of-season live biomass of Spartina patens as an estimate of aboveground production and detrital standing stocks in Year 7. For each survey, 10 quadrats $\left(0.0625 \mathrm{~m}^{2}\right)$ were haphazardly tossed in the Spartina patens habitat of each creek for a total of 50 quadrats. Samples were taken at least $5 \mathrm{~m}$ from the creek-side $S$. alterniflora/S, patens border, the stunted $S$. alterniflora/S. patens border, and the upland terrestrial border. Although the extent of $S$. patens can be $>100 \mathrm{~m}$ from the $S$. alterniflora/S. patens border, samples were taken within $75 \mathrm{~m}$ of the $S$. alterniflora/S. patens border. Samples were taken on either side of the tidal creek along a 250-300 m length of creek for a sampling area of $4-5$ ha creek $^{-1}$. All grass (live and standing dead shoots) within the quadrat was clipped flush to the sediment surface. Collectors worked quickly from the corners inward to catch fast-moving invertebrates. Some individuals (primarily fast-moving amphipods and spiders) escaped collection but were recorded. Common and readily identifiable species were identified to species level. Spiders, of which there are at least 4 morphospecies (pers. obs.), were lumped into one category because they often escaped, thus making reliable identification difficult. The 2 different color morphs of Orchestia grillus (orange and brown) were also recorded. Orchestia is nominally brown in body color, but it becomes orange and alters its behavior when parasitized by a trematode, making it more susceptible to predation by the final host of the trematode-the 
shorebirds (Bousfield \& Heard 1986). Johnson et al. (2009) showed that enrichment led to increased abundances of parasitized Ulhorchestia spartinophila, which is an amphipod species in low-marsh Spartina alterniflora habitats in these marshes.

To determine the potential influence of changes in live Spartina patens biomass and detrital stocks on invertebrates, grass (live and standing dead shoots) was collected from each quadrat in 2010. Material was sorted by species and by living vs. dead litter, dried to a constant weight (typically $2 \mathrm{~d}$ ) at $70^{\circ} \mathrm{C}$, and weighed. The 3 numerically dominant invertebrates: the gastropod Melampus bidentatus, the amphipod Orchestia grillus, and the isopod Philoscia vittata (hereafter referred to generically) are considered detritivores (Rietsma et al. 1982, Thompson 1984, Rietsma et al. 1988) and may thus be influenced by changes in S. patens biomass. Orchestia and Philoscia use their mandibles to shred vegetation and Melampus uses a radula to scrape the surface of sediments and leaves. Melampus and Orchestia are known to graze on microbial decomposers (e.g. fungi; Lopez et al. 1977, Graça et al. 2000).

The biomass $\left(\mathrm{g} \mathrm{m}^{-2}\right)$ of Melampus, Orchestia, and Philoscia was determined. For Orchestia and Philoscia, 30 ind. from reference sites and 30 from nutrient enriched sites were randomly selected and dried to a constant mass at $70^{\circ} \mathrm{C}$. No difference in average individual weights was detected between treatments (2-sample $t$-test, $\mathrm{p}>0.05$ ); thus, all 60 ind. species ${ }^{-1}$ were pooled to generate an average per-capita weight. Biomass $\left(\mathrm{g} \mathrm{m}^{-2}\right)$ was determined as the average per-capita dry weight multiplied by the animal density per quadrat for Philoscia and Orchestia.

For Melampus, 50 different sized snails (range: 5.1 to $13.5 \mathrm{~mm}$ shell height) were collected haphazardly from reference creeks and used to determine the following statistical relationship between shell height and shell-free dry weight:
For 2010 surveys, 3 diversity measures were estimated for each quadrat in PRIMER (Clarke \& Warwick 2001): richness $(S)$, evenness (Pielou's index $J^{\prime}$ ), and Shannon's diversity index $\left(H^{\prime}\right)$. Diversity indices may be skewed by lumping spiders into one broad category and results should be interpreted with caution.

\section{Statistical analysis}

The effects of nutrient enrichment on invertebrate diversity $\left(S, J^{\prime}, H^{\prime}\right)$, density, biomass, and the percentage of juvenile Melampus were analyzed using $t$-tests. Only the densities of the numerically dominant invertebrates (Melampus, Orchestia, Philoscia) and predators (spiders and Tabanus) were analyzed. $t$-tests were also employed to examine the effect of nutrient enrichment on live aboveground Spartina patens shoots and detrital stocks. Prior to analysis, the average data of the 10 quadrats creek $^{-1}$ was determined; thus for each parameter, $\mathrm{n}=2$ for nutrient enrichment, and $\mathrm{n}=3$ for the reference creeks. Melampus shell heights were binned in $0.5 \mathrm{~mm}$ intervals treatment ${ }^{-1}$ and the effect of enrichment on the size distributions was analyzed using a 2-sample Kolmogorov-Smirnov test for distributions. Each year of treatment was analyzed separately. All univariate analyses were conducted in R (R Development Core Team 2009).

To examine the effect of enrichment at the community level, non-metric multidimensional scaling (nMDS) and analysis of similarities (ANOSIM) were conducted on 2010 survey data based on Bray-Curtis similarity matrices. To determine the percent contribution of species driving any differences between communities, similarity percentages (SIMPER) were calculated. Community analyses were conducted in PRIMER (Clarke \& Warwick 2001).

\section{RESULTS}

Twelve categories of macroinvertebrates were observed from the surveys conducted in the Spartina patens marsh (Table 1). Although insects had the highest categorical richness $(n=7)$, the community was numerically dominated by 3 non-insect taxa: Melampus, Philoscia, and Orchestia (combined relative abundance: $97 \%$ of the community; Table 1). These were also the most frequently occurring invertebrates ( $\geq 96 \%$ of the quadrats; Table 1$)$.

The densities of Melampus, Orchestia, Philoscia, and total invertebrates were significantly higher in and juveniles as $<5.5 \mathrm{~mm}$ shell height. 
enriched than in reference creeks in Year 6 (96 to $199 \%$ increase, $t$-test, $\mathrm{p} \leq 0.037$; Fig. 2, Table 2). The same trends were observed in Year 7 except that the effect on Orchestia densities was not significant (Fig. 2, Table 2). The density of parasitized Orchestia was higher in enriched than in reference creeks in both years, with Year 6 density being significantly higher ( $t$-test, $\mathrm{p}=0.018$; Fig. 2, Table 2). Tabanus larvae (adults are commonly known as 'greenhead

Table 1. Relative abundance and frequency of occurrence of macroinvertebrates collected from Spartina patens high marsh in the Plum Island Estuary, MA, USA. Values calculated from quadrats pooled across all creeks $(n=50)$ from Year 7 survey. G: gastropod, I: isopod, A: amphipod, Ar: arachnid, In: insect, B: bivalve

\begin{tabular}{|lcc|}
\hline Species & $\begin{array}{c}\text { Relative } \\
\text { abun- } \\
\text { dance (\%) }\end{array}$ & $\begin{array}{c}\text { Frequency } \\
\text { of occur- } \\
\text { rence (\%) }\end{array}$ \\
\hline Melampus bidentatus $^{\mathrm{G}}$ & 68.96 & 100 \\
Philoscia vittata $^{\mathrm{I}}$ & 19.72 & 98 \\
Orchestia grillus $^{\mathrm{A}}$ & 7.39 & 96 \\
Spiders $^{\text {Ar }}$ & 2.04 & 62 \\
Insect nymphs $^{\text {In }}$ & 1.14 & 26 \\
Tabanus sp $^{\text {In }}$ & 0.27 & 20 \\
Ladybug $^{\text {In }}$ & 0.11 & 8 \\
Ann-Tabanus dipteran larvae $^{\text {In }}$ & 0.11 & 8 \\
Geukensia demissa $^{\mathrm{B}}$ & 0.11 & 6 \\
Beetle larvae $^{\text {In }}$ & 0.08 & 6 \\
Weevils $^{\text {In }}$ & 0.05 & 2 \\
\end{tabular}

flies') densities did not differ between treatments in Year 6 but were significantly higher $(238 \%)$ in enriched than in reference creeks in Year 7 ( $t$-test, $\mathrm{p}=$
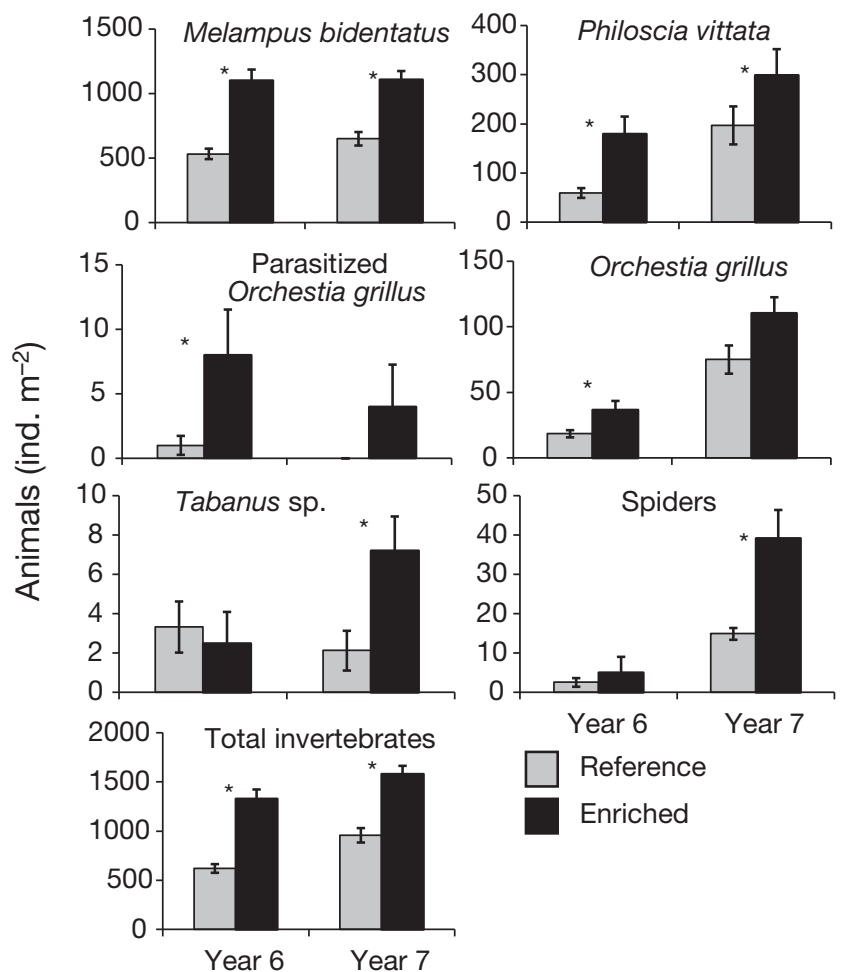

Fig. 2. Mean densities $( \pm \mathrm{SE})$ of invertebrates collected in late summer (August-September) in the Spartina patensdominated high marsh in Plum Island Estuary, MA. $t$-test results: ${ }^{*} \mathrm{p}<0.05,{ }^{* *} \mathrm{p}<0.01$, and ${ }^{* * *} \mathrm{p}<0.001$

Table 2. Mean densities $\left( \pm \mathrm{SE}_{\text {i }}\right.$ ind. $\mathrm{m}^{-2}$ ) of macroinvertebrates collected in late summer (August-September) in the Spartina patens high marsh in the Plum Island Estuary, MA, USA. Significant values are in bold. Means and SEs were calculated from replicates pooled by treatment. $t$-tests were conducted using values averaged by creek within treatments; thus, $\mathrm{n}=2$ for nutrient enriched creeks and $n=3$ for reference creeks. Response to enrichment: \% change enriched vs. reference creeks

\begin{tabular}{|c|c|c|c|c|c|}
\hline Species & Reference & Enriched & $\begin{array}{c}\text { Response to } \\
\text { enrichment (\%) }\end{array}$ & $t$ & $\mathrm{p}$ \\
\hline \multicolumn{6}{|l|}{ Year 6} \\
\hline Melampus bidentatus & $532 \pm 40$ & $1099 \pm 87$ & 107 & 3.58 & 0.037 \\
\hline Parasitized Orchestia grillus & $1 \pm 0.7$ & $8 \pm 3.5$ & 700 & 4.70 & 0.018 \\
\hline Total Orchestia grillus & $18.7 \pm 2.7$ & $36.5 \pm 7.2$ & 96 & 3.67 & 0.035 \\
\hline Philoscia vittata & $60.0 \pm 9.9$ & $179.5 \pm 35.8$ & 199 & 15.78 & $<0.001$ \\
\hline Spiders & $2.6 \pm 1.1$ & $5 \pm 1.5$ & 92 & 0.97 & 0.402 \\
\hline Tabanus sp. & $3.3 \pm 1.3$ & $2.5 \pm 1.6$ & -25 & -0.44 & 0.692 \\
\hline Total inverts & $623 \pm 44$ & $1329 \pm 96$ & 113 & 4.27 & 0.024 \\
\hline \multicolumn{6}{|l|}{ Year 7} \\
\hline Melampus bidentatus & $649 \pm 52$ & $1108 \pm 66$ & 71 & 4.29 & 0.023 \\
\hline Parasitized Orchestia grillus & $0 \pm 0$ & $4 \pm 3.3$ & - & 2.24 & 0.111 \\
\hline Total Orchestia grillus & $75.2 \pm 10.7$ & $110.4 \pm 12.3$ & 47 & 1.66 & 0.195 \\
\hline Philoscia vittata & $197.3 \pm 38.6$ & $299.2 \pm 53.0$ & 52 & 3.79 & 0.032 \\
\hline Spiders & $14.9 \pm 4.1$ & $39.2 \pm 7.2$ & 163 & 3.95 & 0.029 \\
\hline Tabanus sp. & $2.1 \pm 1.0$ & $7.2 \pm 1.8$ & 238 & -3.8 & 0.032 \\
\hline Total inverts & $959 \pm 73$ & $1579 \pm 86$ & 65 & 4.51 & 0.020 \\
\hline
\end{tabular}


0.032; Fig. 2, Table 2). Arachnid densities in enriched creeks were at least twice those in reference creeks in both years but were significantly higher only in Year 7 ( $t$-test, $\mathrm{p}=0.029$; Fig. 2, Table 2).

The biomass $\left(\mathrm{g} \mathrm{m}^{-2}\right)$ of Melampus, Orchestia, and Philoscia was significantly higher in enriched than in reference creeks in Year 6 (96 to 200\%, $t$-test, $\mathrm{p} \leq$ 0.047; Fig. 3, Table 3). In Year 7, the same significant trend in biomass was observed for Melampus and Philoscia but not for Orchestia (Fig. 3, Table 3).

Melampus shell heights ranged from 4 to $11 \mathrm{~mm}$ and were not different between treatments in either year ( $t$-tests, p $>0.213$ ). The overall proportion of juveniles (<5.5 mm shell height) in the Melampus population was low (1.5 to $8.5 \%$ ) with no differences detected between treatments in either year ( $t$-tests, $\mathrm{p}>0.560$ ). Although the modal shell height for each treatment was similar each year (6 to $7 \mathrm{~mm}$ ), there was a significant difference in the size frequency distribution between treatments for each year, with a slight shift to larger snails in enriched creeks (Kolmogorov-Smirnov test, $\mathrm{p}<0.001$; Fig. 4).

No difference in categorical richness, evenness or Shannon's diversity index was detected between treatments (t-test, $\mathrm{p}>0.178)$. Community composition significantly differed between treatments (ANOSIM, Global R =0.161, p=0.004; Fig. 5). SIMPER analysis revealed that the 3 numerically dominant species were responsible for $92 \%$ of these differences (Melampus, 58\%; Philoscia, 26\%; and Orchestia, 8\%).

In terms of live aboveground biomass and detritus, Spartina patens constituted at least $95 \%$ of the dry weight in quadrats in Year 7. No differences in liveshoot biomass or detrital stocks were detected between treatments ( $t$-test, $p>0.469$; Fig. 6).

\section{DISCUSSION}

After $7 \mathrm{yr}$ of nutrient enrichment, the density and biomass of the major constituents of the macroinvertebrate community in the Spartina patens habitat were significantly higher in the enriched than in ref-
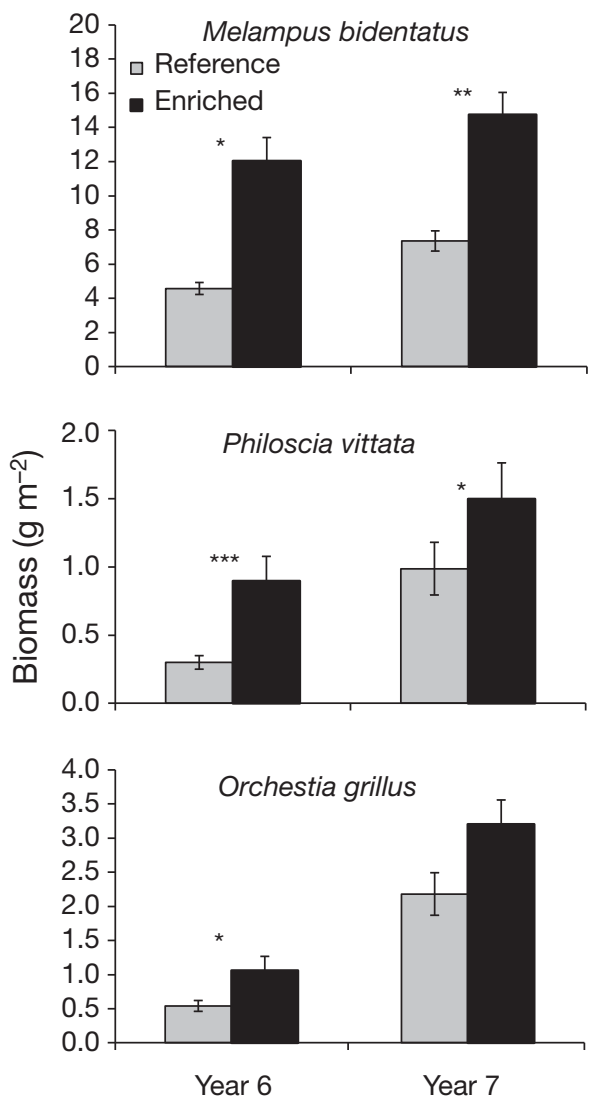

Fig. 3. Mean biomass $( \pm \mathrm{SE})$ of dominant invertebrates collected in late summer (August-September) in the Spartina patens-dominated high marsh in Plum Island Estuary, MA. $t$-test results: ${ }^{*} \mathrm{p}<0.05,{ }^{* *} \mathrm{p}<0.01$, and ${ }^{* * *} \mathrm{p}<0.001$

Table 3. Mean biomass $\left( \pm \mathrm{SE}_{;} \mathrm{g} \mathrm{m}^{-2}\right.$ ) of detritivores collected in late summer (August-September) in the Spartina patens high marsh in the Plum Island Estuary, MA, USA. Significant values are in bold. Means and SEs were calculated from replicates pooled by treatment (enriched $\mathrm{n}=20$, reference $\mathrm{n}=30$ ). $t$-tests, however, were conducted using values averaged by creek within treatments; thus, $\mathrm{n}=2$ for nutrient enriched creeks and $\mathrm{n}=3$ for reference creeks. Response to enrichment: \% change enriched vs. reference creeks

\begin{tabular}{|c|c|c|c|c|c|}
\hline Species & Reference & Enriched & $\begin{array}{c}\text { Response to } \\
\text { enrichment (\%) }\end{array}$ & $t$ & $\mathrm{p}$ \\
\hline \multicolumn{6}{|l|}{ Year 6} \\
\hline Melampus bidentatus & $4.58 \pm 0.35$ & $12.03 \pm 1.38$ & 163 & 3.25 & 0.047 \\
\hline Orchestia grillus & $0.54 \pm 0.08$ & $1.06 \pm 0.21$ & 96 & 3.67 & 0.035 \\
\hline Philoscia vittata & $0.30 \pm 0.05$ & $0.90 \pm 0.18$ & 200 & 15.78 & $<0.001$ \\
\hline \multicolumn{6}{|l|}{ Year 7} \\
\hline Melampus bidentatus & $7.36 \pm 0.59$ & $14.75 \pm 1.30$ & 100 & 10.17 & 0.002 \\
\hline Orchestia grillus & $2.18 \pm 0.31$ & $3.20 \pm 0.36$ & 47 & 0.454 & 0.681 \\
\hline Philoscia vittata & $0.99 \pm 0.19$ & $1.50 \pm 0.27$ & 52 & 3.79 & 0.032 \\
\hline
\end{tabular}




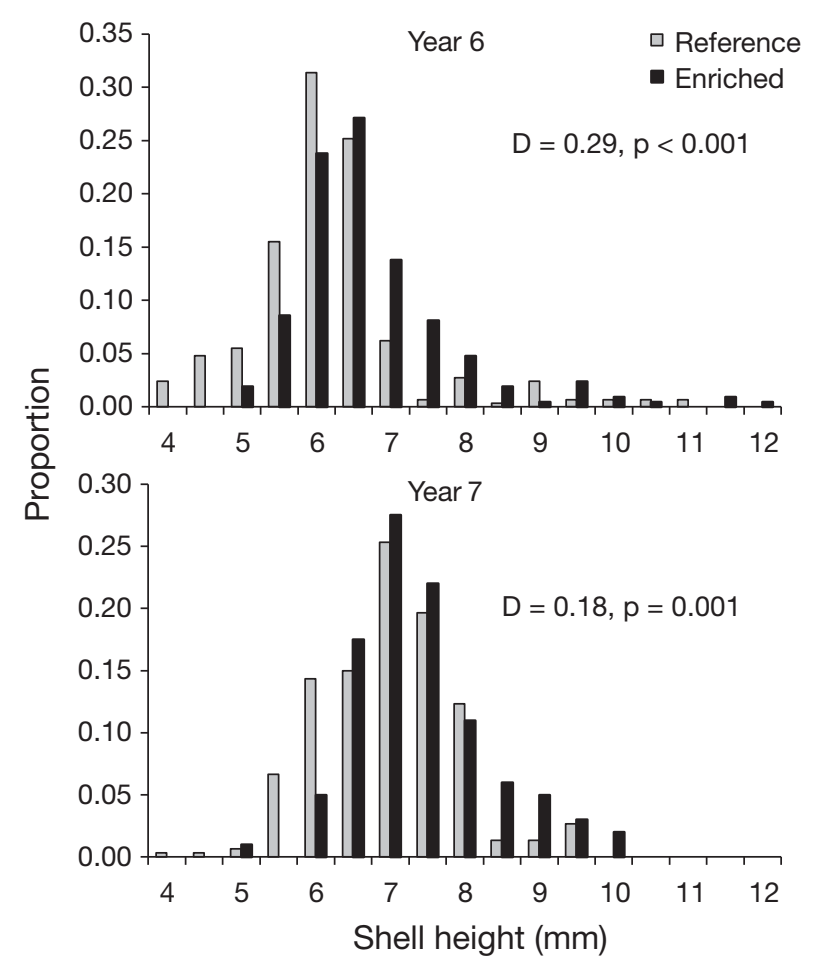

Fig. 4. Melampus bidentatus. Size frequency distributions of shell heights for Years 6 and 7 of nutrient enrichment. The effect of nutrient enrichment on distributions was tested using a Kolmogorov-Smirnov test

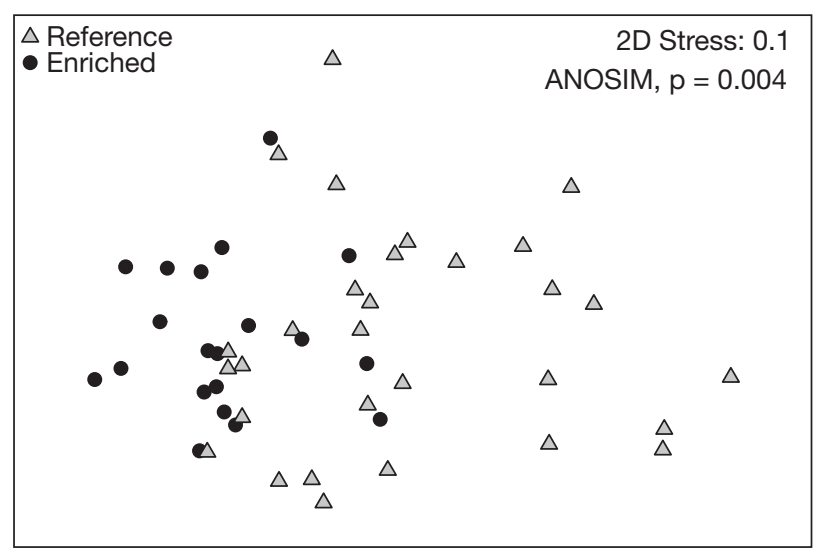

Fig. 5. Non-metric multidimensional scaling display of highmarsh invertebrate community similarities in enriched and reference creeks based on Bray-Curtis similarity matrices of 2010 surveys

erence creeks. These results agree with previous studies that found increased invertebrate densities and/or biomass in response to nutrient enrichment in marshes (Bertness et al. 2008, Johnson \& Fleeger 2009, Wimp et al. 2010). The densities of the 3 dominant taxa (Melampus, Orchestia, and Philoscia) were significantly higher (47 to $199 \%$ ) in enriched than in

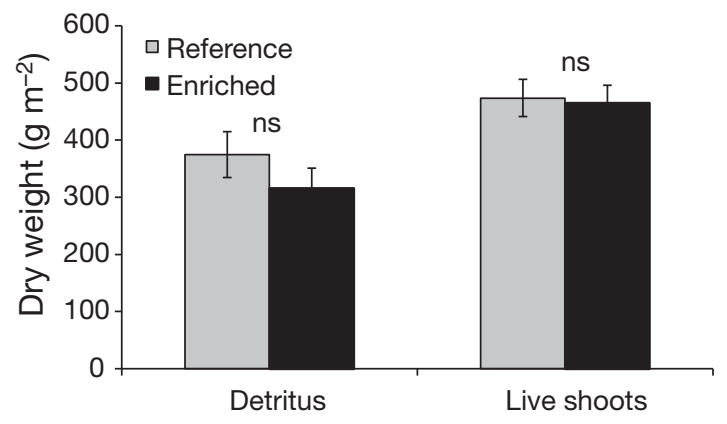

Fig. 6. Spartina patens. Mean dry weight $( \pm \mathrm{SE})$ of aboveground detritus and live shoots collected from clip plots in August 2010. ns: not significant (based on $t$-tests)

reference creeks, which drove the significantly higher trend of total invertebrate densities in enriched creeks. After $7 \mathrm{yr}$ of nutrient enrichment, Tabanus larvae and spider densities in enriched creeks were at least double those in reference creeks. Both Tabanus larvae and spiders are predators of small, high-marsh arthropods (including Philoscia and Orchestia) and the large increase of potential prey in enriched creeks likely contributed to the density increase in these predators.

No abundance data existed for high-marsh invertebrates prior to nutrient enrichment. Abundances were estimated in Years 2 and 3 of nutrient enrichment using passive collectors (litterbags). These were small mesh bags filled with Spartina alterniflora litter placed on the high-marsh surface for $2 \mathrm{wk}$ (see Johnson et al. 2009 for detailed methods). Using this method, I found no differences in abundances of major taxa (amphipods, isopods, and spiders) or community structure (unpubl. data) between treatments. This method, however, could not be used to estimate Melampus abundances because snails do not colonize bags. Although the litterbag method used in Years 2 and 3 of enrichment is not directly comparable to the clip-plot methods used in Years 6 and 7, the 2 sets of data both suggest a cumulative effect of enrichment on high-marsh invertebrate abundances that may take several years to detect.

The biomass $\left(\mathrm{g} \mathrm{m}^{-2}\right)$ of Melampus, Philoscia, and Orchestia was significantly higher in enriched than in reference creeks. For Melampus, this was a function of increased (by 5 to $8 \%$ ) individual shell height and a large density increase (by 70 to $110 \%$ ) in enriched creeks relative to reference creeks. Although the mean shell height for Melampus was not significantly different between treatments, the size frequency distributions were significantly different, with a slight shift to larger snails in enriched creeks. Because I did not determine dry weights of indi- 
vidual Orchestia and Philoscia specimens from the quadrats, I can only suggest that the higher dry weights in enriched creeks versus reference creeks for these species are due to higher densities.

There are several mechanisms by which nutrient enrichment may lead to increased invertebrate densities including enhanced food supply and/or food quality. Melampus, Philoscia and Orchestia are considered detritivores that facultatively consume Spartina grasses (Lopez et al. 1977, Rietsma et al. 1982, Thompson 1984, Rietsma et al. 1988). Enrichment neither stimulated the end-of-season biomass of live Spartina patens, nor did it alter the detrital stocks. Detrital stocks in reference creeks (350 g dry wt $\mathrm{m}^{-2}$ ) was high relative to detritivore biomass $\left(\sim 10 \mathrm{~g}\right.$ dry wt $\mathrm{m}^{-2}$ for Melampus, Orchestia and Philoscia combined). Herjanto \& Thomas (1995) determined that Melampus bidentatus, which is the most abundant invertebrate found in this study, has a production:biomass ratio of 3:1 in Bermudan mangroves. Using this P:B ratio and the highest biomass (14.75 g $\mathrm{m}^{-2}$ ) from the current study for Melampus, production can be estimated at $44.25 \mathrm{~g} \mathrm{~m}^{-2} \mathrm{yr}^{-1}$ in these marshes. Thus, it is unlikely that detritivore production is limited by the quantity of $S$. patens detritus. Improved litter quality (increased $N$, lower lignin content) due to enrichment may have led to increased detritivore density and biomass (Valiela et al. 1984, Rietsma et al. 1988). In 2009, live shoots of $S$. patens had higher $\% \mathrm{~N}$ and lower $\mathrm{C}: \mathrm{N}$ in enriched vs. reference creeks (D. S. Johnson et al. unpubl. data). Moreover, Melampus, Philoscia, and Orchestia are opportunitistic feeders and are thus not strict detritivores (Thompson 1984, Galván 2008). Stimulations of other carbon sources (e.g. algae, bacteria, fungi) by nutrient enrichment may have also led to increased invertebrate densities. Benthic microalgal biomass is relatively low in the high marsh and enrichment has not resulted in increased biomass of this food source (Deegan et al. 2007). Decomposer biomass found on $S$. patens litter, which can be an important carbon source for detritivores such as Orchestia (Lopez et al. 1977), was stimulated by enrichment (D. S. Johnson et al. unpubl. data).

My results contrast with those of McFarlin et al. (2008) who found no fertilization effects on Melampus densities in a Georgia (USA) salt marsh. The authors noted that their plot size $\left(1 \mathrm{~m}^{2}\right)$ may have been insufficient to elicit a strong aggregative response (McFarlin et al. 2008). The scale of enrichment in the current study encompassed entire tidal creeksheds and I was able to assess ecosystem-wide responses of Melampus. Thus, the observed numeri- cal responses of Melampus likely derive from increased production of individuals rather than a net migration of adult snails into the experimental plots. The duration of this experiment may have also been important. In New England, Melampus lay eggs on Spartina alterniflora and $S$. patens stems in early summer (Spelke et al. 1995, author's pers. obs.). Planktonic veligers emerge 10 to 30 d later, depending on the next tidal submergence (Apley 1970, Russell-Hunter et al. 1972), and remain in the water for 6 wk (Apley 1970). Spats settle at a shell height of $680 \mu \mathrm{m}$ and grow to only 1 to $2 \mathrm{~mm}$ in the first year (Apley 1970). Thus, the small size of first-year cohorts may make detection difficult and these tiny individuals might not have been included in many density estimates. Therefore, it may require $>1 \mathrm{yr}$ to detect changes in Melampus densities due to enrichment, to allow the first-year cohorts of snails to grow to detectable size classes.

Increased invertebrate densities elicited by nutrient enrichment have potential consequences for vertebrate predators such as fish and birds. High-marsh invertebrates can be important prey for nekton, such as the killifish Fundulus heteroclitus (Allen et al. 1994, Deegan et al. 2007) and migratory shorebirds (Buchsbaum et al. 2009, Johnson et al. 2009). An intriguing consequence of nutrient enrichment on trophic interactions involves the parasitism of amphipods. Uhlorchestia spartinophila lives in the intertidal low marsh, is normally brown and forages in vegetated, protected habitats (i.e. among Spartina alterniflora stems). When parasitized by the trematode Levinseniella byrdi (Bousfield \& Heard 1986), the amphipod's body color changes from brown to orange and the orange individuals forage in exposed habitats (e.g. unvegetated creek walls; Fig. 1) at low tide (Johnson et al. 2009). This results in increased vulnerability to predation by shorebirds (Johnson et al. 2009), which are the final hosts of the trematode (Bousfield \& Heard 1986). Orchestia, like U. spartinophila, can be parasitized by L. byrdi (Bousfield \& Heard 1986) and responds similarly. In the current study, I found more parasitized Orchestia in the high marsh in enriched than in reference creeks $(700 \%$ more in Year 6$)$. It is likely that the enrichment-associated increase in the density of parasitized amphipods is partly due to increased densities of the total population; however, sampling only the high marsh underestimates the true densities of parasitized amphipods. Parasitized individuals of both Orchestia and $U$. spartinophila migrate to exposed creek-wall habitats (a 1-3 m vertical surface exposed at low tide; Fig. 1) (Johnson et al. 2009, author's pers. obs.). Thus, nutrient enrichment has 
consequences for habitat usage of these invertebrates and can alter fundamental trophic interactions (Johnson et al. 2009).

My results suggest that nutrient enrichment has potential consequences for litter decomposition, which is an important ecosystem function in detritusdominated ecosystems such as salt marshes. Melampus, Orchestia, and Philoscia are the typical dominant invertebrates of the Spartina patens-dominated high marsh in New England marshes (Fell et al. 1982, Fell \& Williams 1985, present study). Thus, higher detritivore densities may lead to increased litter decomposition. In New England marshes, S. patens senesces in the early fall and 'lays down' to form a dense canopy or mat of standing dead shoots near the sediment surface. This standing dead canopy provides both a shaded habitat and a food source for these detritivores (Thompson 1984, Galván 2008). Both Orchestia and Philoscia are shredders, while Melampus scrapes Spartina tissue using a radula (Thompson 1984). In nutrient enriched creeks, the turnover of Spartina litter may thus be accelerated (Valiela et al. 1984) due to increased detritivores and direct stimulation of decomposers.

Based on ANOSIM results, the community structure of invertebrates differed between treatments. In $4 \mathrm{~m}^{2}$ experimental plots, Wimp et al. (2010) observed that fertilizations altered the structure of arthropod communities, with the change being attributed to increased Spartina alterniflora production that led to increased species richness. In the current long-term enrichment experiment, changes in end-of-season live biomass of $S$. patens in the high marsh or in invertebrate species richness were not observed. The community differences detected here appear to be driven primarily by abundance increases in the detritivore community (responsible for $92 \%$ of the community dissimilarity).

My results highlight that even infrequently flooded high-marsh habitats are susceptible to long-term eutrophication effects through changes in invertebrate community structure and trophic interactions and increasing abundances across multiple trophic levels (detritivores and predators). These results generally add to the evidence that variation in nitrogen inputs can affect community structure and abundance of saltmarsh consumers (Deegan et al. 2007, Bertness et al. 2008, Fleeger et al. 2008, Johnson \& Fleeger 2009, Johnson et al. 2009, Wimp et al. 2010). As eutrophication continues to afflict coastal ecosystems, it is important to include high-marsh habitats in our understanding of how eutrophication affects the structure and function of salt marshes.
Acknowledgements. I thank K. Lockfield, A. Mui, A. Ritter, I. Robinson, M. Short, M. Tragash, and S. Wilkins for hours of diligent critter catching in the field; all interns and students of the Marine Biological Laboratory's Marshview Field Station who helped maintain the nutrient enrichment treatments since 2004; J. Fleeger and L. Deegan for their always insightful comments; and 4 anonymous reviewers whose comments improved this manuscript. The National Science Foundation funded this work under grant nos. 9726921, 0213767, 0816963, 1058747, and 0423565.

\section{LITERATURE CITED}

Allen EA, Fell PE, Peck MA, Gieg JA, Guthke CR, Newkirk MD (1994) Gut contents of common mummichogs, Fundulus heteroclitus L., in a restored impounded marsh and in natural reference marshes. Estuaries 17:462-471

Apley ML (1970) Field studies on life history, gonadal cycle and reproductive periodicity in Melampus bidentatus (Pulmonata: Ellobiidae). Malacologia 10:381-397

Apley ML, Hunter RD (1972) Early life-history of Melampus and the significance of semilunar synchrony. Biol Bull 143:623-656

Bertness MD, Crain C, Holdredge C, Sala N (2008) Eutrophication and consumer control of New England salt marsh primary productivity. Conserv Biol 22:131-139

Bousfield EL, Heard RW (1986) Systematics, distributional ecology, and some host-parasite relationships of Uhlorchestia uhleri (Shoemaker) and Uhlorchestia spartinophila, new species (Crustacea, Amphipoda), endemic to salt marshes of the Atlantic coast of North America. J Crustac Biol 6:264-274

Buchsbaum RN, Deegan LA, Horowitz J, Garrit RH, Giblin AE, Ludlam JP, Shull DH (2009) Effects of regular salt marsh haying on marsh plants, algae, invertebrates and birds at Plum Island Sound, Massachusetts. Wetlands Ecol Manage 17:469-487

> Charles H, Dukes JS (2009) Effects of warming and altered precipitation on plant and nutrient dynamics of a New England salt marsh. Ecol Appl 19:1758-1773

Clarke KR, Warwick RM (2001) Change in marine communities: an approach to statistical analysis and interpretation, 2nd edn. PRIMER-E, Plymouth

Darby FA, Turner RE (2008) Below- and aboveground biomass of Spartina alterniflora: response to nutrient addition in a Louisiana salt marsh. Estuaries Coasts 31: $326-334$

> Deegan LA, Bowen JL, Drake D, Fleeger JW and others (2007) Susceptibility of salt marshes to nutrient enrichment and predator removal. Ecol Appl 17:S42-S63

Environmental Protection Agency (2002) Mid-Atlantic integrated assessment (MAIA) estuaries 1997-1998. Summary report. US Environmental Protection Agency, Office of Research and Development, National Health and Environmental Effects Research Laboratory, Atlantic Ecology Division, Narragansett, RI

Fell PE, Williams JH (1985) Distribution of the snail, Melampus bidentatus, and the mussel, Geukensia demissa, along the Pataguanset Estuary (Connecticut) in relation to salinity and other tidal marsh invertebrates. Nautilus 99:22-28

Fell PE, Olmstead NC, Carlson E, Jacob W, Hitchcock D, Sibler G (1982) Distribution and abundance of macroin- 
vertebrates on certain Connecticut tidal marshes, with emphasis on dominant molluscs. Estuaries 5:234-239

Fleeger JW, Johnson DS, Galván KA, Deegan LA (2008) Top-down and bottom-up control of infauna varies across the saltmarsh landscape. J Exp Mar Biol Ecol 357:20-34

Galván KA (2008) Diet of saltmarsh consumers. PhD dissertation, Louisiana State University, Baton Rouge, LA

- Gedan KB, Bertness MD (2010) How will warming affect the salt marsh foundation species Spartina patens and its ecological role? Oecologia 164:479-487

Graça MA, Newell SY, Kneib RT (2000) Grazing rates of organic matter and living fungal biomass of decaying Spartina alterniflora by three species of salt-marsh invertebrates. Mar Biol 136:281-289

Herjanto, Thomas MLH (1995) Population characteristics of melampid and littorinid snails in three mangrove-dominated sites of Bermuda. Caribb J Sci 31:274-280

Johnson DS, Fleeger JW (2009) Weak response of saltmarsh infauna to ecosystem-wide nutrient enrichment and fish predator reduction: a four-year study. J Exp Mar Biol Ecol 373:35-44

Johnson DS, Fleeger JW, Galván KA, Moser EB (2007) Worm holes and their space-time continuum: spatial and temporal variability of macroinfaunal annelids in a northern New England salt marsh. Estuaries Coasts 30: 226-237

> Johnson DS, Fleeger JW, Deegan LA (2009) Large-scale manipulations reveal that top-down and bottom-up controls interact to alter habitat utilization by saltmarsh fauna. Mar Ecol Prog Ser 377:33-41

Lopez GR, Levinton JS, Slobodkin LB (1977) The effect of grazing by the detritivore Orchestia grillus on Spartina litter and its associated microbial community. Oecologia 30:111-127

McFarlin CR, Brewer J, Buck TL, Pennings S (2008) Impact of fertilization on a salt marsh food web in Georgia. Estuaries Coasts 31:313-325

Mendelssohn IA (1979) The influence of nitrogen level, form, and application method on the growth response of Spartina alterniflora in North Carolina. Estuaries 2: 106-112

Miller WB, Egler FE (1950) Vegetation of the Wequetequock-Pawcatuck tidal marshes, Connecticut. Ecol Monogr 20:143-172

Editorial responsibility: Richard Osman, Edgewater, Maryland, USA
Niering WA, Warren RS (1980) Vegetation patterns and processes in New England salt marshes. Bioscience 30: 301-307

R Development Core Team (2009) R: a language and environment for statistical computing. $\mathrm{R}$ Foundation for Statistical Computing, Vienna, Austria, available at www.R-project.org

Rietsma CS, Valiela I, Sylvester-Serianni A (1982) Food preferences of dominant salt marsh herbivores and detritivores. PSZN I: Mar Ecol 3:179-189

Rietsma CS, Valiela I, Buchsbaum R (1988) Detrital chemistry, growth, and food choice in the salt-marsh snail (Melampus bidentatus). Ecology 69:261-266

Russell-Hunter WD, Apley ML, Hunter RD (1972) Early lifehistory of Melampus and the significance of semilunar synchrony. Biol Bull 143:623-656

Spelke JA, Fell PE, Helvenston LL (1995) Population structure, growth and fecundity of Melampus bidentatus (Say) from two regions of a tidal marsh complex in Connecticut. Nautilus 108:42-47

Stiling P, Brodbeck BV, Strong DR (1991) Population increases of planthoppers on fertilized salt-marsh cord grass may be prevented by grasshopper feeding. Fla Entomol 74:88-97

Thompson LS (1984) Comparison of the diets of the tidal marsh snail, Melampus bidentatus and the amphipod, Orchestia grillus. Nautilus 98:44-53

> Valiela I, Teal J, Sass WJ (1975) Production and dynamics of salt marsh vegetation and the effects of experimental treatment with sewage sludge. J Appl Ecol 12:973-981

Valiela I, Wilson J, Buchsbaum R, Rietsma C, Bryant D, Foreman K, Teal J (1984) The importance of chemical composition of salt marsh litter on decay rates and feeding by detritivores. Bull Mar Sci 35:261-269

> Warren RS, Fell PE, Grimsby JL, Buck EL, Rilling GC, Fertik RA (2001) Rates, patterns, and impacts of Phragmites australis expansion and effects of experimental Phragmites control on vegetation, macroinvertebrates, and fish within tidelands of the lower Connecticut River. Estuaries 24:90-107

> Wimp GM, Murphy SM, Finke DL, Huberty AF, Denno RF (2010) Increased primary production shifts the structure and composition of a terrestrial arthropod community. Ecology 91:3303-3311

Submitted: March 28, 2011; Accepted: July 19, 2011 Proofs received from author(s): September 26, 2011 